\title{
A Critical Discussion on Max Weber's Argument of Buddhism as an Anti- Political Religious Philosophy
}

Rev. Beligalle Dhammajoti ${ }^{1}$

\section{Abstract}

In spite of its relevance in everyday life, some perceive Buddhism is to be a philosophy that does not talk about mundane matters such as socio-economic and political aspects of life, therein only supramundane facts are discussed. For instance, Max Weber conceptualizes that Buddhism is asocial, anti-political and other-worldly religion. Such preoccupied assertions and mistaken-beliefs about original teachings of the Buddha still thrive. In this paper, thus teachings of the Buddha pertaining to the political philosophy are examined in order to refute the preoccupied assertions that Buddhism is antipolitical. The embryonic form of ideas and concepts pertaining to the Buddhist Political philosophy are spread throughout the Canonical texts, mainly in Sutta Pitaka, Vinaya Pitaka and in Jātaka stories in which significant philosophical delineations are explained as ethical and didactic theories and can explicitly be used in today's political arena. Finally, by explaining the political teachings of the Buddha, the paper proves that Max Weber's misconception is groundless and unjustifiable.

${ }^{1}$ Department of Pali $\&$ Buddhist Studies, University of Ruhuna-Sri Lanka beligalledj@gmail.com

Keywords: Aggaññasutta, Anti-political religion, Cakkavatti-sihanādasutta, Kūtadantasutta, Max Weber 


\section{Original Article}

\section{INTRODUCTION}

Among many theistic religions, Buddhism stands as an atheistic doctrine that teaches a great ethical philosophy that can be practised by any person. The main objective of Buddhism is to show the 'reality' of beings, their environment and universe and guides people to the ultimate happiness. Buddhist teachings can be categorized into two sections, such as,

i. Fundamental teachings: Four Noble Truths, Eightfold Path, Interdependent origination, Causality, Doctrine of Kamma and Punabbhava, etc.

ii. Secondary teachings: Buddhist Social Philosophy, Buddhist Environmental Philosophy, Buddhist Economic Philosophy, Buddhist Political Philosophy, Philosophy of history etc.

Fundamental teachings are conducive to terminate the samsāric suffering (suffering which arises in the process of recurrent births and deaths) and would pave the way for ultimate happiness, and the secondary teachings are mainly expounded for the welfare and happiness of secular life. The political philosophy explained in Buddhism, therefore, is conducive to the appropriate political governance of a country. Max Weber, mistakenly holds the opinion that Buddhism is asocial and anti-political. In this research paper, an effort has been made to prove that there is a precise political philosophy that is more appropriate to modern society.

\section{RESEARCH PROBLEM}

Although Max Weber is a worldrenowned sociologist and is considered to be the "Father of Sociology of Religion", it is difficult to agree with his opinions and arguments since evidence refutes his preoccupied ideas about Buddhism. His statement that "Buddhism is anti-political" should be methodically examined. This research paper strives to explore whether Buddhism is anti-political as specified by Max Weber in his book "The Religion of India" (Weber, 1967) comparing with the doctrinal teachings of Buddhism.

\section{RESEARCH OBJECTIVE}

By examining some discourses of the SuttaPitaka, VinayaPitaka and some other related teachings found in the Jataka stories, this research paper tries to prove that there is a clear-cut political philosophy expounded by the Buddha in the $6^{\text {th }}$ century B.C. and to show how such teachings explained in the early Buddhist philosophy helpnegate the opinion of Max Weber.

\section{RESEARCH METHOD}

The literary survey was employed for this research work. First, the statement of Max Weber was taken into consideration carefully. Then the theories, teachings, information, and exegetical analysis pertaining to Buddhist political philosophy were collected from some discourses of the 


\section{Original Article}

Sutta Pitaka, exegetical texts and the Jataka stories. The research is limited to the Aggañnasutta, the Cakkavattisihanādasutta, the Kütadantasutta, Suttanipāta, essential parts of the Vinaya Pitaka and some Jâtaka stories in order to prove that there is a political philosophy in Buddhism. Finally, this paper provides a conclusion that Max Weber's opinion of Buddhist political philosophy is misleading and unjustifiable.

\section{DISCUSSION}

\section{Max Weber's Opinion}

Max Weber arrived at a conclusion that 'Buddhism is asocial, antipolitical, and other-worldly religion'. Weber states: "It is a specifically unpolitical and anti-political status religion. Buddhism had no sort of tie with any sort of "social" movement, nor did it run parallel with such and it has established no 'social-political goal'(Weber, 1967:206-226). This can be considered a groundless misconception that Max Weber specified. It seems that he rushed into this conclusion without referring to Early Buddhist Texts, and he might have considered just the noticeable societal condition that he experienced during his visit to India.

Stanislav Andreski(1984) critically describes his view on Max Weber's ideas on religion such as: "He does not restrict the applicability of his generalizations to a particular country or period and offers them as indications of cross-cultural tendencies. He illustrates them by examples of debatable correctness and does not even attempt to substantiate them by marshalling evidence. The truth is that historical data needed to justify such generalizations were not available to him and scarcely exist even now" (Andreski, 1984:94). It is accepted that Max Weber's opinions are a source of new suggestions and foundations for research works and they paved the way for hundreds of new researches and findings. It seems some of his opinions on religion, especially on Buddhism are debatable.

Besides the basic philosophical teachings, Buddhism categorically introduces secondary teachings in regard to economic, environmental, political and social philosophy. Although the term 'Politics' means 'power in public life and being able to influence decisions that affect the country, it really means philanthropy or service to human beings' (Rahula,1974). A variety of political systems are found in the world today: Capitalism, Communism, Socialism, and Democracy etc. Whatever the political system may be, the major policy undercurrent of the system is to provide a service to society.

\section{Buddha's First Counsel}

When sixty-one (61) arahants in the world appeared, the Buddha gave a major advice to them; "Carathabhikkhavecārikam bahujanahitāya'bahujanasukhāyalokanuka 


\section{Original Article}

mpāyaatthāyahitāyasukhāyadevamanussā nam" (Vinaya II, 1879:21) that means: "Monks, Walk on tour for the blessing of the many, for the happiness of the many people, out of compassion for the world, for the welfare, the blessing, the happiness of devas and men". This is the major objective of the arahanta society (Society of Perfected Ones) and it can be considered to be a great sociopolitical thought. Therefore, it is not incorrect to say that by giving his first counsel and guidance to first sixty arahants, the Buddha initiated his socio-economic, political and spiritual service for a sustainable society. Regarding the first counsel of the Buddha, Prof. Asanga Tilakaratne categorically asserts: 'The concept of 'welfare and happiness of the multitude' (bahujana-hitabahujanasukha) which is essentially a political goal, is found from the very beginning of the ministry of the Buddha' (Tilakaratne, 2011:154).

\section{Origin of the State}

In the ancient world, people believed that the king or the State organization was a creation of the god. During the medieval period, in Europe, various notions were found regarding the origin of the state. In accordance with Divine Right theory, States are established by God or the gods, and the ruler has the divine right to rule (Ariyadeva, 2009:254; Sharma, 1985:19). With regard to the origin of the State, the 'Social contract theory' can be considered to be a well-known theory.
Thomas Hobbes, Plato, J.J. Rousseau, and John Locke presented the Social Contract Theory (Barker, 1960). 'It concerns the legitimacy of the authority of the State over the individual. Individuals surrender some of their freedom and submit to the authority of the ruler in exchange for protection of their remaining rights or maintenance of the social order'(Barker, 1960:32). Some scholars believe that Buddhism also expounds the social contract theory. A.L. Basham (1954) suggests that the legend of 'Mah̄a-sammata' (The Great Elect) mentioned in the Sanskrit Buddhist text Mahāvastu gives the account of social contract theory (Basham, 1954:82). It is to be noted here that the Aggaññasutta of the Digha Nikāya also provides a detailed account of 'Mahā-sammata' (DighaNikaya III, 1976:93).

\section{Governmental Contract Theory}

Buddhist explanations are closer to the 'Governmental Contract

Theory'.Aggaññasuttaexplains:

"....Now those beings, Vasettha, gathered themselves together, and bewailed these things, saying: From our evil deeds, sirs, becoming manifest, inasmuch as stealing, censure, lying, punishment have become known, what if we were to select a certain being, who should be wrathful when indignation is right, who should ensure that which 


\section{Original Article}

should rightly be censured and

should banish him who

deserves to be

banished?"(DighaNikāya III,

1976:93).

The sutta further explains that the nature of the first ruler of the earth as: "Chosen by each and every member of community", is what meant by Mahā Sammata; so Mahā Sammata (the Great Elect) was the first standing phrase to arise" (Digha Nikāya III,1976:p.93; Dialogues of the Buddha III,1991:p.88). According to Aggaññasutta, it is very clear that political authority totally depends on the consent of the public.

\section{Reasons for Origin of the State}

Before explaining the appointment of the first ruler, the Great Elect, Aggañnasutta provides various reasons for this appointment for ruling the world society.

i. The appearance of private property system (At the outset, there was a system of common property in the world. Later, they divided off the rice fields and set boundaries. Then, the private property system appeared)

ii. The manifestation of evil deeds, such as stealing, censure, lying, and punishment

iii. Organization of family life and social life on earth (Digha Nikāya III, 1976:93).

Because of these reasons, people elected Mahāsammata, ${ }^{2}$ a proper person with a juridical power to safeguard private property and family life, and also to administer society so that it does not encounter corruptions. He was called 'Mahāsammata' since he was elected by the consent of people. Therefore, this idea is closer to Governmental contract theory, and it may also be termed as the "SocioGovernmental Contract Theory".

\section{Expressions of Khattiya and Rāja}

Furthermore, Aggañ̃nasutta explains the true meanings of the two expressions of khattiya and rāja. 'Lord of the fields is what is meant by khattiya; so khattiya (Noble) was the next expression to arise' (Digha Nikāya III, 1976:93). The term indicates the ownership of land. This expression is mainly related to agriculture and production that is considered to be the very foundation of society. Then, Aggañ̃asutta explains the term 'rājä' (or king) ${ }^{3}$ and, it means 'He who gladdens others by righteousness' (Digha Nikāya III, 1976:87-93). Here, it is said that the major objective of the king is to delight his subjects in righteous ways. These are the ancient and important political expressions interpreted in Aggañ ñasutta.

\section{Nature of the Political Authority}

In the ancient and medieval period, rulers promulgated the idea that they rule the country by the authorization of God or gods or any other divine permission. This notion is totally rejected inAggañnasutta. It explains that the origin of the political authority comes from the common consent of 


\section{Original Article}

ISSN: 2279-3933

people. The Great Elect (Mahā Sammata) was given his juridical power by the common consent of whole community. Therefore, according to Buddhist notions it never depends on any divine power. In order to maintain political authority in a manner consistent with accepted ethical principles, the ruler should observe ten Cakkavatti principles. The ruler or the government should take the common consent of its citizens for any general development affairs or special projects of the country.

\section{Vox Populi}

According to Buddhists discourses, the king's sovereignty is a secondary matter. His first concern should be the VoxPopuli, (Consent of the People) stick to principles of the country and welfare of its people. Cakkavattisihanādasutta elucidates the idea of Voxpopuli in this way: 'By his own ideas, forsooth, he governed his people; and they so governed, differently from what they had been, did not prosper as they used to do under former kings who had carried out the Aryan duty of a Sovereign king' (Digha Nikāya III,1976:93). The Pāli term found in the Cakkavattisihanādasutta, "samatena"4 suggests, 'negligence of people's voice', in other words the political leaders tend to misuse political authority in line with own accord thereby neglecting voice of the populace. When a ruler works only by his own ideas, the country would be in disarray, everything would turn upside down. According to Buddhist suttas, fundamental condition of ruling is to respect to Vox Populi under any system of government.

\section{CAKKAVATTI-VATTĀNI OR THE STATE POLICIES}

\section{Cakkavatti-vattāni and Righteousness}

The fundamental policies of a state can be found clearly in Cakkavattisihanādasutta. At first, the ruler must be a righteous one and should rule the country righteously (Digha Nikâya iii, 1976:p.93). The kingship or the political authority is not the paternal heritage ${ }^{5}$ or 'pettikamdāyajjam' (Digha Nikāya III, 1976:93). The sutta explains that 'dibbamcakkaratam' (Celestial Wheel) is not the paternal heritage. Here, the Celestial Wheel symbolizes the political authority of governance. Under the Cakkavatti-vattāni, (government policies) the major principle of the governance is explained as: '...Leaning on the Dhamma, honouring, respecting and revering it, doing homage to it, hallowing it, being thyself a Dhammabanner, a Dhamma-signal, having the Dhamma as your master ...' (DighaNikāya III,1976:61). This statement emphatically affirms the commitment of 'righteousness' for good governance ${ }^{6}$. The fundamental policies explained in Cakkavattisihanādasutta are closely related to Politics and Political philosophy. Therefore, the argument on Buddhism as an anti-political philosophy is significantly contrasting. 


\section{Original Article}

Writing an introduction to Cakkavattisihanādasutta, Professor Rhys Davids(1991) asserts: "The point of moral-and in this fairy tale the moral is the thing-is the reign of Law. Never before in the history of the world had this principle been proclaimed in so thorough-going and uncompromising away"(Dialogues of the Buddha III: 53). According to the summary of Cakkavatti-sihanādasutta, major policies of a kingdom can be listed as follows:

i. Constitutional protections for all living beings including animals and other beings,

ii. Law and State affairs shall be depended on the 'Righteousness',

iii. Alleviation of poverty,

iv. To protect the natural environment,

v. To solve socio-economic crises

These political policies are pertaining to the economy, environment, righteousness, and necessary defence of the country (Digha Nikāya III, 1976:58-70; Dhammajoti, 2000). Even in modern society, these are the expectations that citizens of a country mainly look for. Therefore, it seems that the state policies mentioned in Cakkavattisihanādasutta categorically rejects Max Weber's position.

\section{Root Causes of Social Revolutions}

The root causes of socio-economic and political revolutions are explained in Cakkavatti-sihanādasutta i: '...when there were no means of living (from goods not being bestowed on the destitute) poverty grew rife; from poverty growing rife stealing increased, from the spread of stealing weapons grew great; When weapons were available in large quantities, violence grew apace; from the growth of violence the destruction of life became common, from the frequency of murder, ...lying,... back-biting, ....sexual misconduct, ....harsh speech, frivolous talks, ...covetousness and illwill......false opinions......incest, wanton greed and perverted lust....till finally lack of filial and religious piety and lack of regard for the head (elders) of the clan grew great. ${ }^{7}$ For these things growing, the life-span of those beings and also the comeliness of them wasted away...'(Digha Nikāya III, 1976:70-71).

Here, we find a special Pāli term: "ananuppadiyamāne" and the translation was given to it in Sinhala and English versions are not precise enough to give the correct idea. Translating this passage, Ananda Wijeratne (2011) writes: ' When the wealth of the country is not properly distributed amongst the subjects the rich and poor divide will widen. 'It seems here that Wijeratne (2011) confines to the given meaning in the translation and does not focus on the deeper meaning of this historical word. It is to be noted here that for the term, "ananuppadiyamāne" the better English equivalent translation would be 'when there were no means of living'; and not the 'mal-distribution of wealth' as Wijeratne suggests. The root causes mentioned in Cakkavattisihanādasutta 


\section{Original Article}

for stirring up of revolutions can clearly be seen in everywhere in the world. Explanations of revolutions and their root causes mentioned in the Buddhist discourses are pertaining to the political field. The discussion of social revolution in this sutta directly related to politics of a country.

\section{Four Wrong-causes of Political Life}

According to Sigālasutta of Digha Nikāya, people commit evil deeds from motives of partiality (attachment chandā), enmity $(\operatorname{dos} \bar{a})$, stupidity (mohā) and fear (bhayā) (Digha NikāyaIII, 1976:182). It is clear that some political leaders of the world today, rule their countries in unrighteous ways because of these wrong causes of life. The kings, administrators and other governing bodies essentially are supposed to avoid these four wrong causes of life (agate-gamaniyāni) for righteous and good governance. It is the ultimate accountability of the king to provide a service without any partiality and provide a proper environment for their peaceful living.

\section{Tenfold Rules of Governing}

Tenfold royal duties are prescribed for rulers in Buddhist texts for peaceful and righteous governing. These guidelines provide them to lead their royal life without socio-economic and political blemishes. The tenfold royal duties of a monarch or government are mentioned as follows:

Generosity or alms-giving, (dāna), Morality or controlling of his senses (sila), Liberality or making sacrifices for citizens (pariccāga), Straight forwardness in his political dealings (ajjava), Kind-heartedness and gentleness (maddava), Self-restriction (tapa), Non-anger (akkoda),

Compassion or non-hurtfulness (avihimsā), Tolerance (khanti), and Non-opposition (avirodhana) (Jātaka I,1990:399; Jātaka III,1990:274).

These are referred to as "dasarājadhamma' or ten points of righteousness-governing explained in various Jātaka stories (previous birth stories of the Buddha). The specific way of governing is explained in Jātaka stories: 'he ruled in righteousness, not shaking the tenfold code of the king'. Therefore, according to Buddhist texts, this tenfold code of governing is an essential part of the ruler. In this way, Jātaka stories provide fundamental socio-economic, political and psychological theories, and many stories are pertaining to political governing, e.g. Mahāsupina Jātaka and Rājovāda Jātaka. Therefore, Buddhist texts prescribe political theories of good governing and it is thus contradictory to assert that Buddhism is anti-political as Max weber suggested.

\section{Sevenfold Conditions of Prosperity}

Vajjian kings followed sevenfold conditions taught by the Buddha and continued to rule their Vajjian confederacy without any socioeconomic problems and any sort of deterioration. Sevenfold doctrines 


\section{Original Article}

(sattaaparihāniyadhamma) paved the way for their progress and was mentioned as follows:

"To hold regular and frequent assemblies; To meet in harmony, break up in harmony, and carry on their business in harmony; To do not authorize what has not been authorized already, and to do not abolish what has been authorized; To honor, respect, revere and salute the elders among them, and consider them worth listening to; To do not forcibly abduct others' wives and daughters and compel them to live with them; To honor, respect, revere and salute the (Vajjian) shrines at home and abroad, not withdrawing the proper support made and given before; Make proper provision for the safety of arahants (PerfectedOnes), so that such arahants may come in future to live there, and those already there may dwell in comfort" (Digha Nikāya II,1982:73-75).

As long as rulers govern their countries under the guidance of these seven conditions, according to the word of the Buddha, they are expected to prosper and not to decline. These conditions are strictly related to the field of political institutions and they pave the way for prosperity, peaceful governance, moral qualities in the country and safeguard of rulers in turn. Mahā-parinibbānasutta further expounds different sets of seven-fold laws pertaining to the progress and prosperity of monks and laypeople.
Therefore, it is clear that Buddhism expounds political theories.

\section{CAKKAVATTI KINGS AND ETHICAL AUTHORITY}

\section{Cakkavatti Kings}

Cakkavatti kings (Wheel-turning Monarchs or Rulers who preserve the law and order) are considered to be the powerful righteous kings who rule their territories with political principles by way of higher ethical values. Three sorts of Cakkavāla kings are mentioned in the Buddhist texts, such as:

i. CakkavālaCakkavatti - AUniversal monarch or Caturanta Cakkavāla who is ruling over four Great continents

ii. Dipa Cakkavatti - A Universal monarch ruling over one continent

iii. Padesa Cakkavatti - A monarch ruling over a part of a continent. This categorical definition is given in various places of fundamental discourses and their commentaries (Sutta Nipāta, 1918:106; Sumangalavilāsini I, 1968:249; Digha Nikāya I, 1983:88; PTS Dictionary, 1992:259).

The given Pāli formula for understanding the nature of a previous Cakkavāla Cakkavattiking is: 'so imam pathavimsāgarapariyamtamadandenaasat thenadhammena abhivijiyaajjhāvasi....' - He lived in supremacy over this earth to its ocean bounds, having conquered it, not by the scourge, not by the sword, but by righteousness (Digha Nikāya III, 


\section{Original Article}

1976:59; Dialogues of the Buddha III, 1991:60). This means that Cakkavāla Cakkavatti monarch is a world ruler and he ruled the world 'without punishment, without weapons, and in a righteous way'. It is clear that Cakkavatti concept found in the Buddhist texts provide a political theory whichmay be more favourable even to modern society. The very foundation of 'Cakkavatti ruling' is 'Dhamma' or 'righteousness'. Therefore, the significance of this political theory is that 'Political Authority', gradually, turns into the 'Ethical Authority' (Dhammajoti, 2000:91).

\section{Ballot System}

In Buddhist sangha assemblies, announcements are made three times, the motion is put three times, and decisions are declared three times in disciplinary matters (Vinaya I, 1964:56; Vinaya II, 1879:89). When there is a moot point in disciplinary matters to be settled among the sangha confraternity, the method of taking votes is used in Buddhist sangha assemblies. They practised three methods of taking votes, viz;

i. Gūlhaka-Secret Ballot,

ii. Vivataka- Open Ballot, and

iii. Sakannajappaka- whispering in the ear (a method of taking votes secretly) (Vinaya II, 1879:99).

Today, the secret ballot and the open ballot systems are practised in global political assemblies. Although this ballot system is very ancient, it has been practised in Buddhist sangha assemblies for more than two thousand six hundred years. This is certainly pertinent to political matters of sangha society and it sets up an example for path to lay society in order to solve disciplinary disputes.

\section{CONCLUSION}

It is clear that Buddhist doctrines, although they are in a narrative style, suggests more favourable political principles for any kind of State whether it is Capitalistic, Socialistic, or Democratic. It seems that Buddhist teachings explained in this paper are closer to Democratic and Socialist system of administration. Even so, under the Capitalistic political system, Buddhist teachings may be applied under the policy of "Righteousness". Cakkavāla Cakkavattitype of ruling is the "World Ruler or Global system of political administration'. The Buddha emphatically states the theory of "Righteousness" in political administration and that type of country is called "the kingdom of Righteousness". In the Buddhist point of view, 'Righteousness' seems to be the fundamental theory of any kind of political governance. Buddhist teachings of the Origin of State, First Counsel of the Buddha, nature of Political Authority, Sevenfold Conditions of Prosperity, Tenfold Rules of Governing, Cakkavatti kings, Ballot systems, Voxpopuli, Root causes of Revolutions, and State policies are directly pertaining to political philosophy of Buddhism. There are 
some other doctrines that reject Max Weber's argument but quite a few among them have been selected here. Therefore, this paper suggests that Buddhism is not anti-political as Max Weber explains, and it clearly contains a favourable political philosophy for the modern world.

\section{NOTES}

1. Horner translates the term 'bahujanahitāya' as 'blessings', but better English equivalent for 'bahujanahitāya' is 'welfare of the many'.

2. The Pāli formula for the statement runs thus: 'Mahajanasammato'tikhoVasetthamahā-sammato, mahasammatotv'evapathamamakkharamupanibbatt $a m^{\prime}$.

3. The Pāli formula for 'rājā' is: "Dhammena pare ranjetitikhoVasettharājā..."

4. 'samatenajanapadampasāsatopubbenāparam janapadāpabbanti....ariyecakkavattivattevattamanānam'; 'samatena' means 'by his own ideas'-(DighaNikāya, III,1976:65)

5. 'nahitetātadibbamcakkaratanampettikamdāyajjam'- (DighaNikāya III,1976:59).

6. 'dhammamyevanissāyadhammamsakkarontod hammamgarukarontodhammammānentodham mampujentodhammamapacāyamāno,

dhammaddhajodhamma-

ketudhammādhipateyyodhammikamrakkhavar ana-guttimsamvidahassu',

(DighaNikāya III,1976:61)

7. '......adhanānamdhaneananuppadiyamānedāli ddiyamvepullamagamāsi, dāliddiye ...adinnādānam..., ...sattham ...., ..pānātipato..., ... musāvāàdo ,...pisunavācāa..., ...kāmesumicchācāro...,

...dvedhammā...pharusavācāsamphappalāpo ca. .... abhijjhā-vyāpado..., micch $\bar{a}-$ ditthi...,..adhammarāgovisamalobhomicchādhammo, ......amatteyyatāapetteyyatāasāmañ̃āātaabrah mañ̃atakule- jetthāpacāyitā. .',(DighaNikāya III,1976:70-71).

\section{References}

Andersen, D. \& Smith, H. (Eds.) (1913)SuttaNipata.Oxford: PTS.

Andreski, S. (1984)Max Weber's Insights and Errors. New York: Routledge

Ariyadeva, W. (2009) The Theory and Practice of Social Revolution in Early Buddhism. Sri Lanka: Buddhist Cultural Centre.

Barker, E. (1960) Social Contract: Essays by Locks, Hume and Rousseau. London: Oxford University Press.

Basham, B.L. (1954) The Wonder that Was India. New York: The Macmillan Co.

Carpenter, J.E. (Ed.) (1976) DighaNikāyaVol. III. London: PTS.

Dhammajoti, B. (2000) Buddhist Economic Philosophy. (In Sinhala). Colombo: Rathna Book Publishers.

Fausboll, V. (Ed.) (1990) JātakaVol. IEJātakaVol. III. London: PTS.

Honour, I.B. (Tr.) (2007) Book of the DisciplineVol. IV. Lancaster: PTS.

Oldenberg, H. (Ed.) (1964) VinayaPitakamVol. I. London: PTS.

Oldenberg, H. (Ed.) (1879) VinayaPitakamVol. II. London: Williams and Norgate.

Rahula, W. (1974) The Heritage of the Bhikkhu. New York: Grove Press, INC.

Rhys Davids, T.W. \& Carpenter, J.E. (Eds.) (1982) DighaNikayaVol. II. London: PTS.

Rhys Davids, T.W. \& C.A.F. (Tr.) (1991) Dialogues of the BuddhaVol. III. Oxford: PTS.

Rhys Davids, T.W. \&Stede, W. (1992) PaliEnglish Dictionary, Oxford:PTS.

Sharma, R.N. (1985) Political PhilosophyDelhi: KN Ram Nath.

Weber, M. (1967) The Religion of India, New York: The Free Press.

Wijeratne, A. (2011) Two Political Perspectives, in Chandawimala, R. and Wijebandara, C. (Eds.), Nanapprabha, Singapore: Ti-sarana Buddhist Association, (pp. 155-165). 


\section{Original Article}

ISSN: 2279-3933

Tilakaratne, A. (2011) Political Metaphor in the Life of the Buddha, in Chandawimala, R. and Wijebandara, C. (Eds.),
Nanapprabha, Singapore: Ti-sarana

Buddhist Association, (pp. 145-154). 